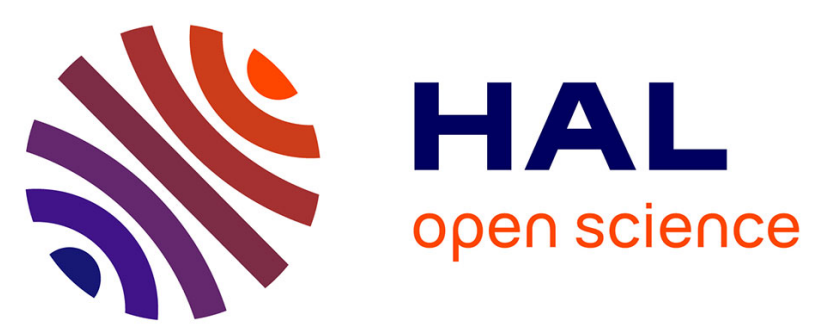

\title{
Reproductive cycle and sex inversion of the seabass, Lates calcarifer, reared in sea cages in french polynesia: histological and morphometric description
}

Yann Guiguen, Chantal Cauty, Alexis Fostier, J. Fuchs, Bernard Jalabert

\section{- To cite this version:}

Yann Guiguen, Chantal Cauty, Alexis Fostier, J. Fuchs, Bernard Jalabert. Reproductive cycle and sex inversion of the seabass, Lates calcarifer, reared in sea cages in french polynesia: histological and morphometric description. Environmental Biology of Fishes, 1994, 39, pp.231-247. 10.1007/BF00005126 . hal-02713703

\section{HAL Id: hal-02713703 \\ https://hal.inrae.fr/hal-02713703}

Submitted on 1 Jun 2020

HAL is a multi-disciplinary open access archive for the deposit and dissemination of scientific research documents, whether they are published or not. The documents may come from teaching and research institutions in France or abroad, or from public or private research centers.
L'archive ouverte pluridisciplinaire HAL, est destinée au dépôt et à la diffusion de documents scientifiques de niveau recherche, publiés ou non, émanant des établissements d'enseignement et de recherche français ou étrangers, des laboratoires publics ou privés. 


\title{
Reproductive cycle and sex inversion of the seabass, Lates calcarifer, reared in sea cages in French Polynesia: histological and morphometric description
}

\author{
Yann Guiguen, ${ }^{1}$ Chantal Cauty, ${ }^{1}$ Alexis Fostier, ${ }^{1}$ Jacques Fuchs ${ }^{2} \&$ Bernard Jalabert ${ }^{1}$ \\ ${ }^{1}$ Laboratoire de Physiologie des Poissons, I.N.R.A., Campus de Beaulieu, 35042 Rennes Cédex, France \\ ${ }^{2}$ Centre Océanologique du Pacifique (COP, I.F.R.E.M.E.R.), BP 7004, Taravao, Tahiti, Polynésie Française
}

Received 1.2.1993 Accepted 5.10.1993

Key words: Protandrous hermaphroditism, Reproduction, Gonads, Barramundi perch, Centropomidae, Pisces

\section{Synopsis}

The reproductive cycle and sex inversion of the protandrous, tropical seabass, Lates calcarifer, reared in seacages in French Polynesia, were studied. In Tahiti, this species exhibits a single annual reproductive period from October to February beginning with the warm and wet season. Sex inversion begins at the end of this reproductive period in post-spawning males. The main histological features of this process were: degeneration of testicular tissue, appearance of peripheral female germinal cells, and centripetal proliferation of ovarian tissue. Completion of sex inversion required profound morphological changes in the gonads because of the strong dimorphism that exists between testis and ovary. All transitional gonads appeared morphologically smaller than testes and typically had a red-pink colour. About $45 \%$ of the three-year-old male stock underwent sex inversion, and males averaged smaller in size than did females and transitional fish.

\section{Introduction}

The tropical seabass or barramundi perch, Lates calcarifer (Block, 1790) belongs to Centropomidae. It is one of the most important species for both aquaculture and fisheries in its area of natural distribution, which extends throughout the whole Indo-Pacific. This species is a freshwater, estuarine and coastal fish, and migrates downstream for spawning (Grey 1987).

The seabass is hermaphroditic (Moore 1979, Davis 1982), and its protandry has been demonstrated by experimental studies involving biopsy (Moore 1979). Its biology and ecology have been studied mostly in Australia and Papua New Guinea (see Grey 1987, Davis 1987 for reviews). In these areas, the species undergoes a complex biological cycle. Spawning takes place in brackish waters, near the mouths of rivers, during the wet season. Eggs, embryos, larvae and juveniles first develop in coastal swamps, and the young of the year migrate upstream at the end of the wet season. They usually remain in freshwater until they reach sexual maturity as males (3-4 years). 'These maturing males migrate downstream at the start of the wet season and, after spawning, males and females can remain in tidal waters or move upstream again. Sex inversion usually take place between 6 and 8 years of age, after several spawnings as males, but Davis (1984) described a sexually precocious population of seabass in which fish change sex at the age of about 4-5 years.

Experiments on seabass rearing have been performed since 1985 at the Oceanological Center of the Pacific (COP, I.F.R.E.M.E.R.), because of a promising potential for aquaculture in French Poly- 

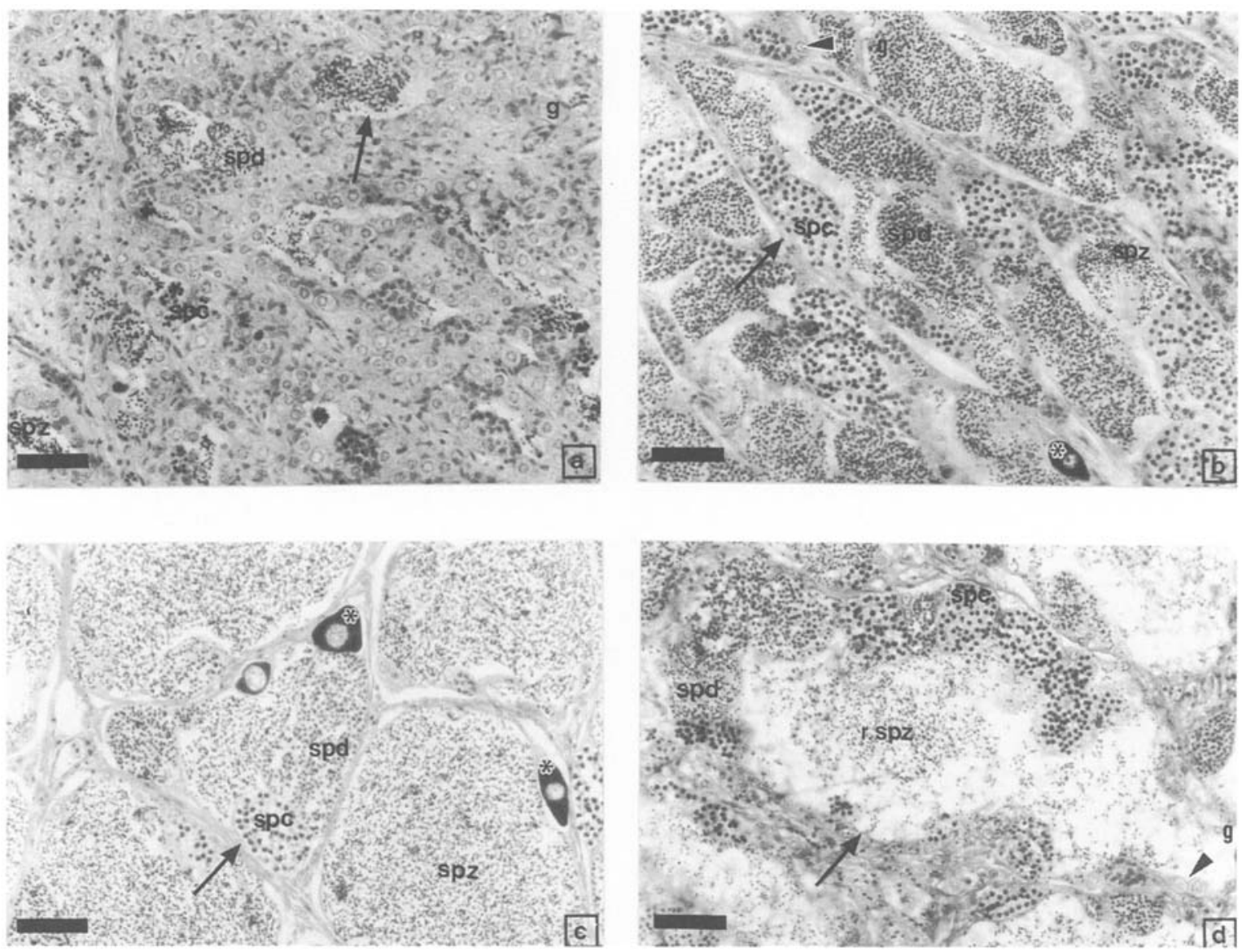

Fig. 1. Testicular maturation stages in Lates calcarifer: a - Testis gonia stage (M1). b - Spermatogenesis stage (M2). c - Spermation stage (M3). d - Post-spawning stage (M4). r.spz = residual spermatozoon, $\mathrm{spc}=$ spermatocytes, $\mathrm{spd}=$ spermatids, $\mathrm{g}=$ gonias, $\mathrm{spz}=\mathrm{spermato}-$ zoon, asterisks indicate previtellogenic oocytes, arrows indicate testicular lobules. All scales $50 \mu \mathrm{m}$.

nesia where lagoons provide exceptional conditions for floating netcage culture (Fuchs 1987, Aquacop et al. 1990). The aim of these experiments was to describe the sexual cycle and the process of sex inversion in the seabass kept in seawater, under the natural conditions of French Polynesia. These data on the sexuality of this species were of prime importance to establish complete breeding control of the seabass, Lates calcarifer, introduced to Tahiti.

\section{Materials and methods}

Larvae of the seabass, Lates calcarifer, were imported from the Primary Production Department of Singapore, and reared in two floating netcages (about $24 \mathrm{~m}^{3}$ volume, $4.80 \times 2.30$ and $2.20 \mathrm{~m}$ depth) anchored in the Vairao lagoon (Tahiti Island, French Polynesia) at the Oceanological Center of the Pacific (I.F.R.E.M.E.R.). They were fed dry, pelleted feed with an automatic feeding system (Fuchs 1987, Aquacop et al. 1990).

Twenty to twenty-five fish, aged three years from hatching at the beginning of the study (October 1988), were sacrificed each month during 14 months from October 1988 to November 1989 (total number of sacrificed fish $\mathrm{N}=309$ ). So, the number of fish per cage ( 155 fish per cage at the beginning of the study) varied over the course of the study. Each fish was killed by a blow to the head and the following data were immediately recorded: Standard length in $\mathrm{mm}(\mathrm{SL})$, body weight in $\mathrm{g}(\mathrm{W})$, gonadal weight in $\mathrm{g}(\mathrm{Wg})$ and visceral weight without gonads in $\mathrm{g}(\mathrm{Wv})$. The gonado-somatic index (GSI) 
was calculated as follows: $\mathrm{GSI}=100 \mathrm{Wg}(\mathrm{W}-\mathrm{Wg}-$ $\mathrm{Wv})^{-1}$.

A piece of one gonad (when possible a cross-section at the mid point) was fixed in Bouin-Holland fluid, dehydrated, embedded in paraffin, and the sections of 4-7 $\mu \mathrm{m}$ were stained with Regaud hematoxylin, Orange $G$ and Aniline blue dyes or with a commercial solution (Giemsa, RAL) of azur eosinate (Gabe 1968). Some gonads were fixed whole, and sections were taken from the anterior, median, and posterior part in order to check for any possible heterogeneity in transitional gonads. Highest oocyte diameters were determined as the mean diameter of the ten largest oocytes within one histological cross-section of the ovary.

Data analysis was performed with a computer program (Statgraphic) for parametric one-way analysis of variance. Multiple range comparisons were performed using a t-test. Differences in the proportion of each sex type was performed by comparison of percentage confidence interval given in Schwartz (1963).

Climatic data (mean over 25 years) were obtained from the meteorological station of TahitiFaaa.

\section{Results}

\section{Reproductive cycle}

\section{Gonadal maturation stages (Table 1)}

Testicular maturation stages. - Male gametogenesis appeared to be a continuous process. All categories of germinal cells, from gonia to spermatozoa, were present in all sampled fish during the entire year. There was a concentric zonation of the germinal cells, and the most advanced stages of spermatogenesis were always located in the central part of the testis. Nevertheless, several different stages of testicular maturation could be distinguished according to the relative abundance of each germinal cell type within the gonad:

Male stage 1 (M1) or testis gonia stage $=$ Predominance of gonia within the testis (Fig. 1a).

Male stage 2 (M2) or spermatogenesis stage = Predominance of spermatocytes and spermatids (Fig. 1b).

Male stage 3 (M3) or spermiation stage $=$ Large parts of the testis were filled with spermatozoa, and the lobular structure of the testis was no longer distinguishable in these areas (Fig. 1c).

Male stage 4 (M4) or post-spawning stage $=$ Most of the testicular lobules were devoid of spermatozoa, but some gonia and spermatogenic cysts remained at the lobule periphery (Fig. 1d).

Whatever the testicular maturation stage, the great majority of the testes (up to $100 \%$ during

Table 1. Gonadal maturation stages in the seabass, Lates calcarifer.

\begin{tabular}{lll}
\hline Sex type & Index & Histological criterion (Gonadal maturation stage) \\
\hline Male & M1 & Mostly gonia (testis gonia) \\
& M2 & Mostly spermatocytes and spermatids (spermatogenesis) \\
& M3 & Mostly spermatozoa (spermiation) \\
& M4 & Testicular lobules devoid of spermatozoa (post-spawning) \\
Transitional & T1 & Degeneration of male testicular tissue \\
& T2 & Appearance of ovarian tissue with still degenerating testicular tissue \\
& T3 & Ovarian tissue $<50 \%$ within histological cross-section (no testicular tissue) \\
& T4 & Ovarian tissue $>50 \%$ within histological cross-section (no testicular tissue) \\
Female & F1 & Gonia and previtellogenic oocytes (previtellogenesis) \\
& F2 & Vitellogenic oocytes $<50 \%$ within histological cross-section (early vitellogenesis) \\
F3 & Vitellogenic oocytes $>50 \%$ within histological cross-section (vitellogenesis) \\
& F4 & Oocytes atresia (atretic) \\
\hline
\end{tabular}



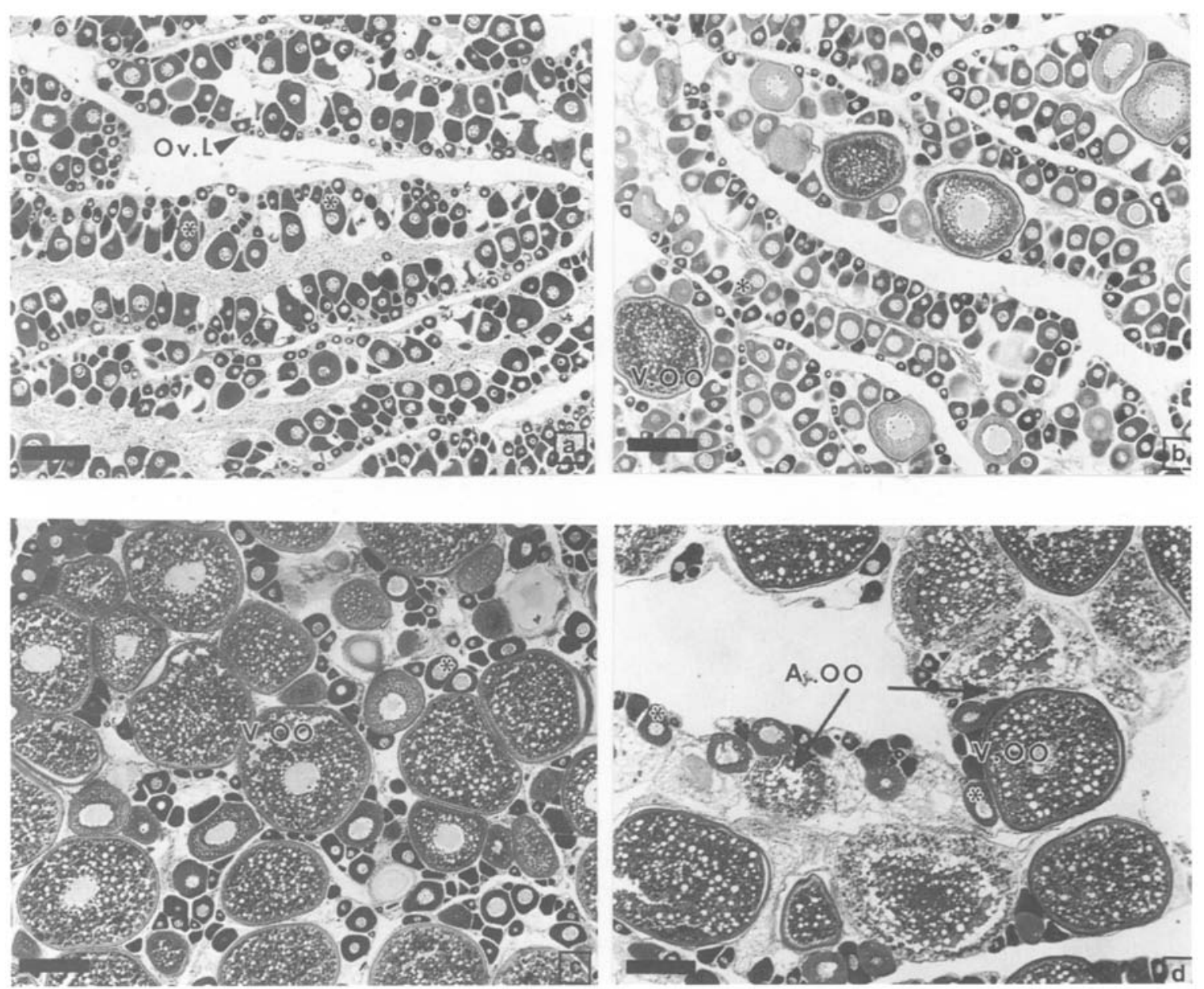

Fig. 2. Ovarian maturation stages in Lates calcarifer: a - Previtellogenesis stage (F1). b-Early vitellogenesis stage (F2). c - Vitellogenesis stage (F3). d - Atretic stage (F4). A.oo = Atretic oocytes, Ov.L = Ovarian lamellae, V.oo = Vitellogenic oocytes, asterisks indicate previtellogenic oocytes. All scales $200 \mu \mathrm{m}$.

some months) contained some previtellogenic oocytes (Fig. 1b, c). These were sometimes numerous, up to several hundred per cross-section. They were most often located, singly or in clusters, near the ventral side of the gonad. The average diameters for the largest 10 oocytes per section were between 20 and $50 \mu \mathrm{m}$ and oocytes never developed beyond this stage in males.

Ovarian maturation stages. - In females, gonia and previtellogenic oocytes were present at all times of the year. Therefore, ovarian maturation stages (Table 1) have been defined according to the relative abundance of vitellogenic and atretic oocytes:

Female stage 1 (F1) or previtellogenesis stage =
The ovary was mainly filled with previtellogenic oocytes arranged within ovarian lamellae. These oocytes were strongly basophilic when stained with hematoxylin and Giemsa (Fig. 2a). Mean diameter of the largest 10 oocytes per section was $73 \pm 16 \mu \mathrm{m}$ $(\mathrm{N}=60)$.

Female stage 2 (F2) or early vitellogenesis stage $=$ Only a few vitellogenic oocytes could be observed, representing less than $50 \%$ of one histological cross-section area of the ovary. These oocytes were larger than the previtellogenic ones, and their cytoplasm had lost their basophilic character (Fig. $2 b$ ). They were surrounded by easily distinguished follicular cells. Mean diameter of the largest 10 oocytes per section was $160 \pm 75 \mu \mathrm{m}(\mathrm{N}=15)$. 
Female stage $3(\mathbf{F 3})$ or vitellogenesis stage $=\mathrm{Vi}-$ tellogenic oocytes occupied more than $50 \%$ of one histological cross-section area of the ovary (Fig. 2c). Mean diameter of the largest 10 oocytes per section was $390 \pm 29 \mu \mathrm{m}(\mathrm{N}=42)$.

Female stage 4 (F4) or atretic stage $=$ A large predominance of atretic oocytes was found within the ovary (Fig. 2d). Mean diameter of the largest $10 \mathrm{oo}-$ cytes per section was $335 \pm 103 \mu \mathrm{m}(\mathrm{N}=7)$.

\section{Reproductive periods}

Two main periods could be distinguished in the reproductive cycle of this species in French Polynesia (Fig. 3, 4).

The resting period (March through September) was characterized by a very low GSI (less than $0.5 \%$ for females and $0.1 \%$ for males). Only a few males and no females were found with gonads at stage 3 . During this period, the temperature continued to increase until March-April, and then decreased. The rainfall decreased, and daylength reached its minimum (11 hours) in June.

The atretic stage (F4) of female gonadal maturation appeared in low proportion in December and February and in all females in March (Fig. 3), then it was soon replaced by a long period of previtellogenesis (F1), from April to August. The beginning of early vitellogenesis (F2) was first detected in July, but the proportion of fish at this stage always remained below $40 \%$ until September.

Active spermiation extended from October to March, but there were still a few males exhibiting spermation (M3) in May, June and July (up to 23\% in May). Between 20 and $80 \%$ of testes were postspawning (M4) until August. The highest proportion of spermatogenesis stage (M2) was recorded at the end of this resting period (from 50 to $90 \%$ after June), and the testis gonia stage (M1) was always below $40 \%$ (maximum in May).

'I he reproductive season was characterized by a high GSI, and nearly all the animals had gonads with gonadal maturation stage 3 (spermation and vitellogenesis). The maximum GSI for females, however, was only reached from November to January ( $\mathrm{p}<0.01$ for October and February). Mean diameters for the largest 10 oocytes per section were between $250 \mu \mathrm{m}$ (October 1989) and $400 \mu \mathrm{m}$ (Octo-

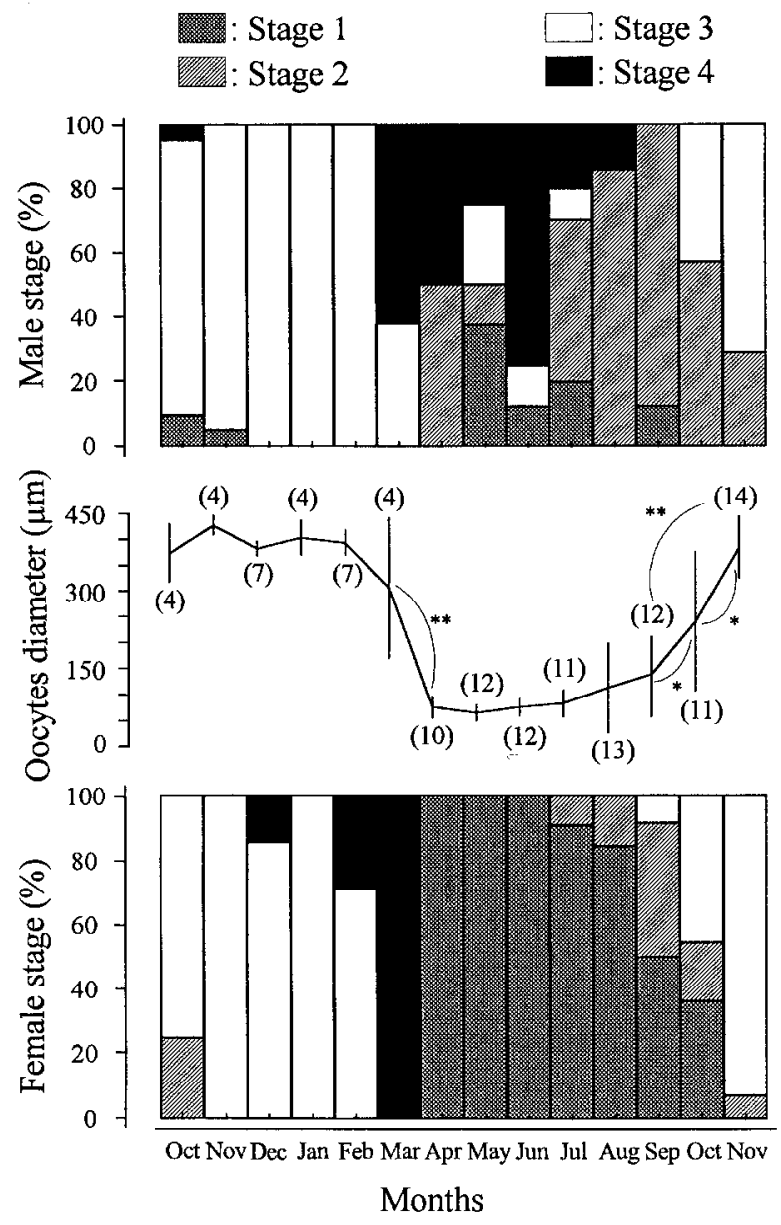

Fig. 3. Gonadal maturation stages and diameters of the largest 10 oocytes per section (number of females in parentheses) during the reproductive cycle of the seabass, Lates calcarifer. Data are expressed as the percentage of male in each gonadal malc stage and of female in each gonadal female stage. Testis gonia stage (M1), spermatogenesis stage (M2), spermation stage (M3), postspawning stage (M4). Previtellogenesis stage (F1), early vitellogenesis stage (F2), vitellogenesis stage (F3), atretic stage (F4). $*=$ significant difference $\mathrm{p}<0.05 . * *=$ significant difference $\mathrm{p}$ $<0.01$.

ber-February 1988). During this period, which extended from October to February, temperatures were increasing, but they did not reach their maximum until March for air temperature and April for water temperature. Rainfall was at its maximum in December and daylength was maximum from October to February (12.5-13 hours).

GSI, percentages of fish with gonads at stage 3, and oocyte diameters were lower during the two 


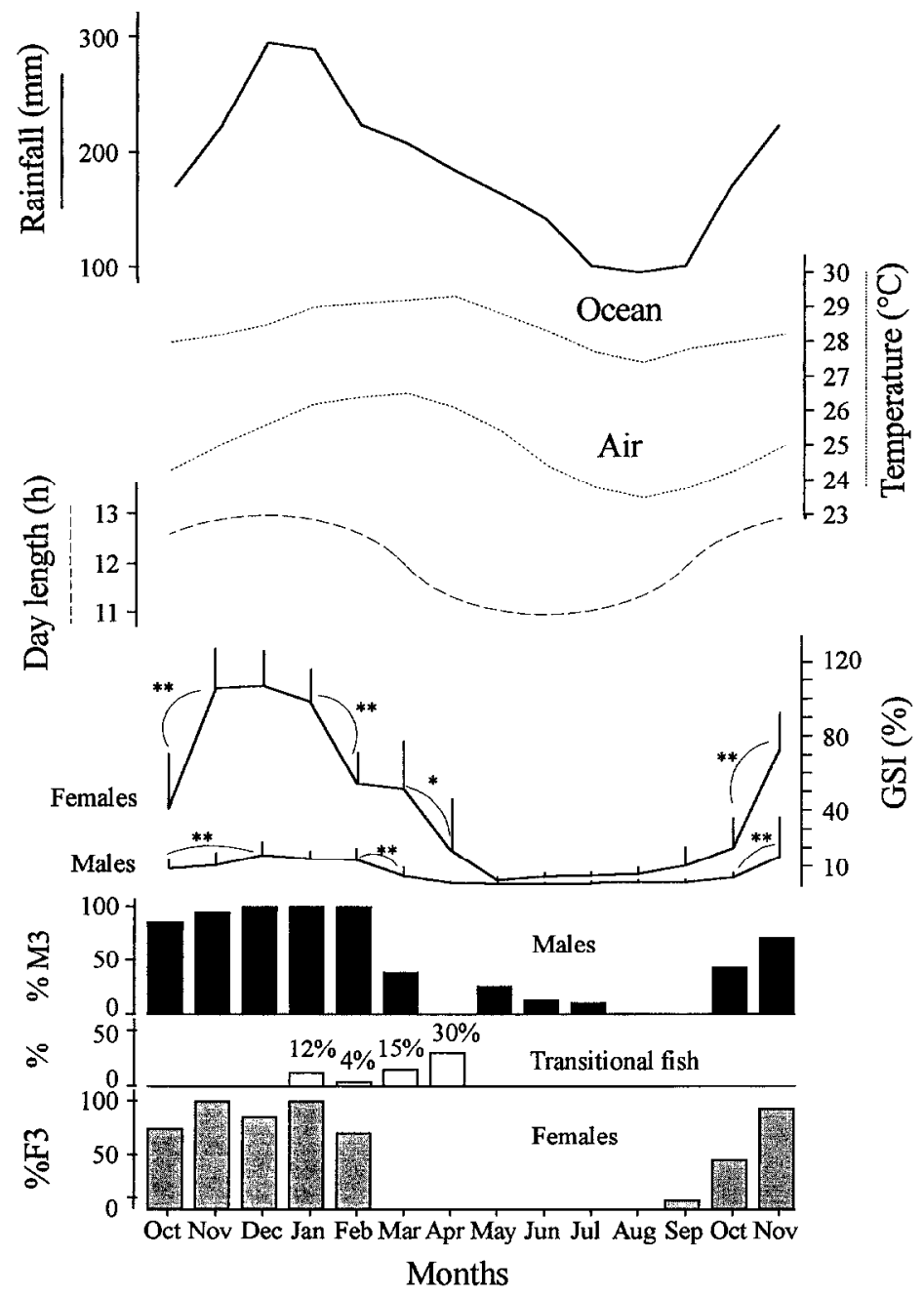

Fig. 4. GSI, percentages of males and females in stage 3 (spermiation and vitellogenesis), percentage of transitional fish, and changes in air and water temperature, daylength, and rainfall during the reproductive cycle of the seabass, Lates calcarifer. $*=$ significant difference $\mathrm{p}<0.05$. $^{* *}=$ significant difference $\mathrm{p}<0.01$.

sampling months of the second year (October and November 1989) than during the preceding year.

\section{Sex inversion}

\section{Description of sex inversion}

The testis is a paired organ, and transverse sections of one gonad (see transverse section of a testis in Figure 5) showed a solid, roughly triangular structure, with two more or less regular latero-dorsal lobes. Efferent ducts were located on the dorsal side while the ventral side was divided into numer- ous lobes. In contrast, the ovary is a paired, hollow organ, showing, in transverse sections (Fig. 5), ovarian lamellae that invade the lumen from the ovarian walls. Because of this strong structural dimorphism between testis and ovary, we assumed that sex inversion in the seabass, Lates calcarifer, would require radical morphological reorganization of the gonad.

Depending on the presence of degenerating testicular tissue and the relative abundance of proliferating ovarian tissue, four stages of sex inversion (T1 to T4) have been defined (see Table 1 and Figure 5):

Transitional stage 1 (T1) $=$ The first signs of sex 


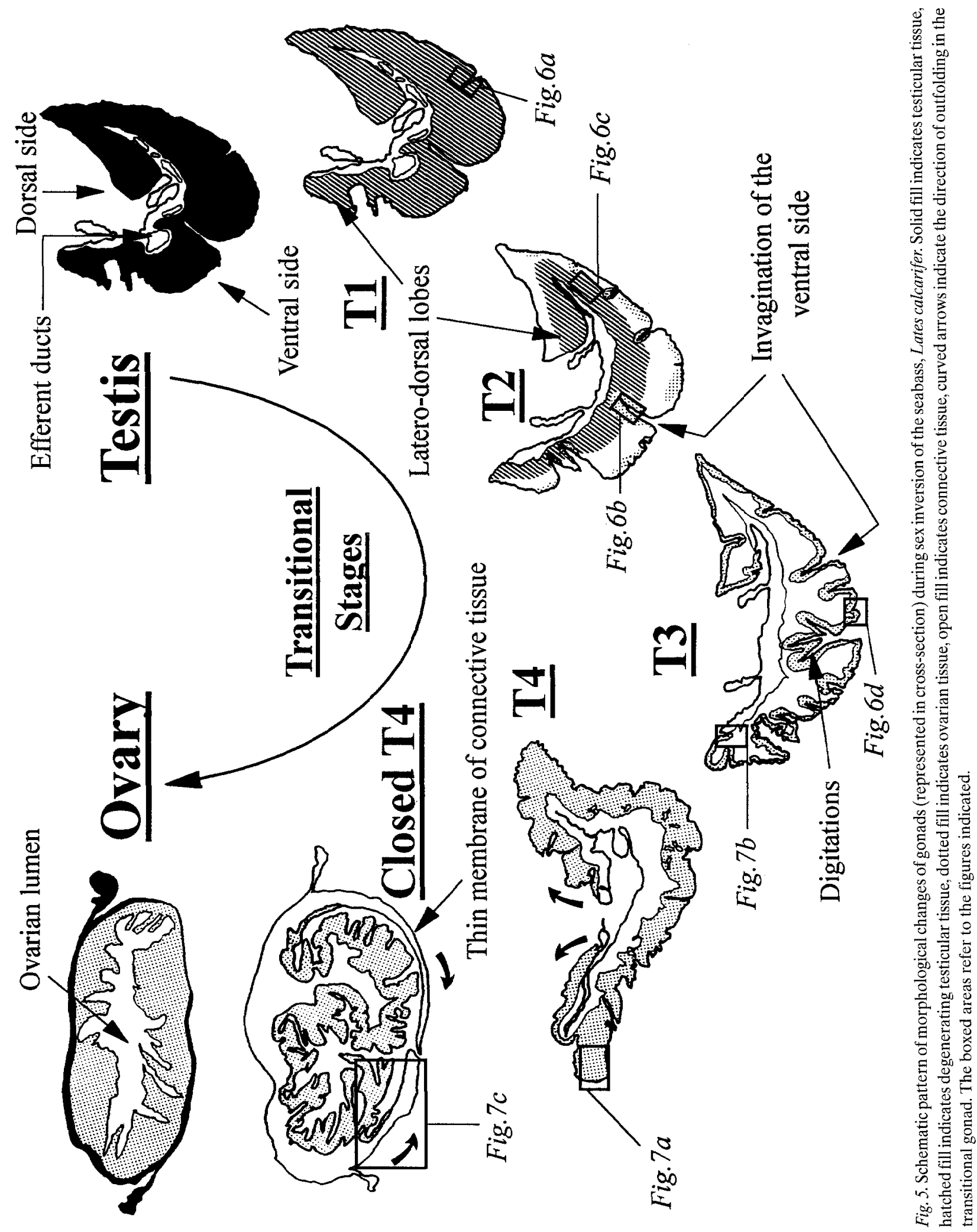



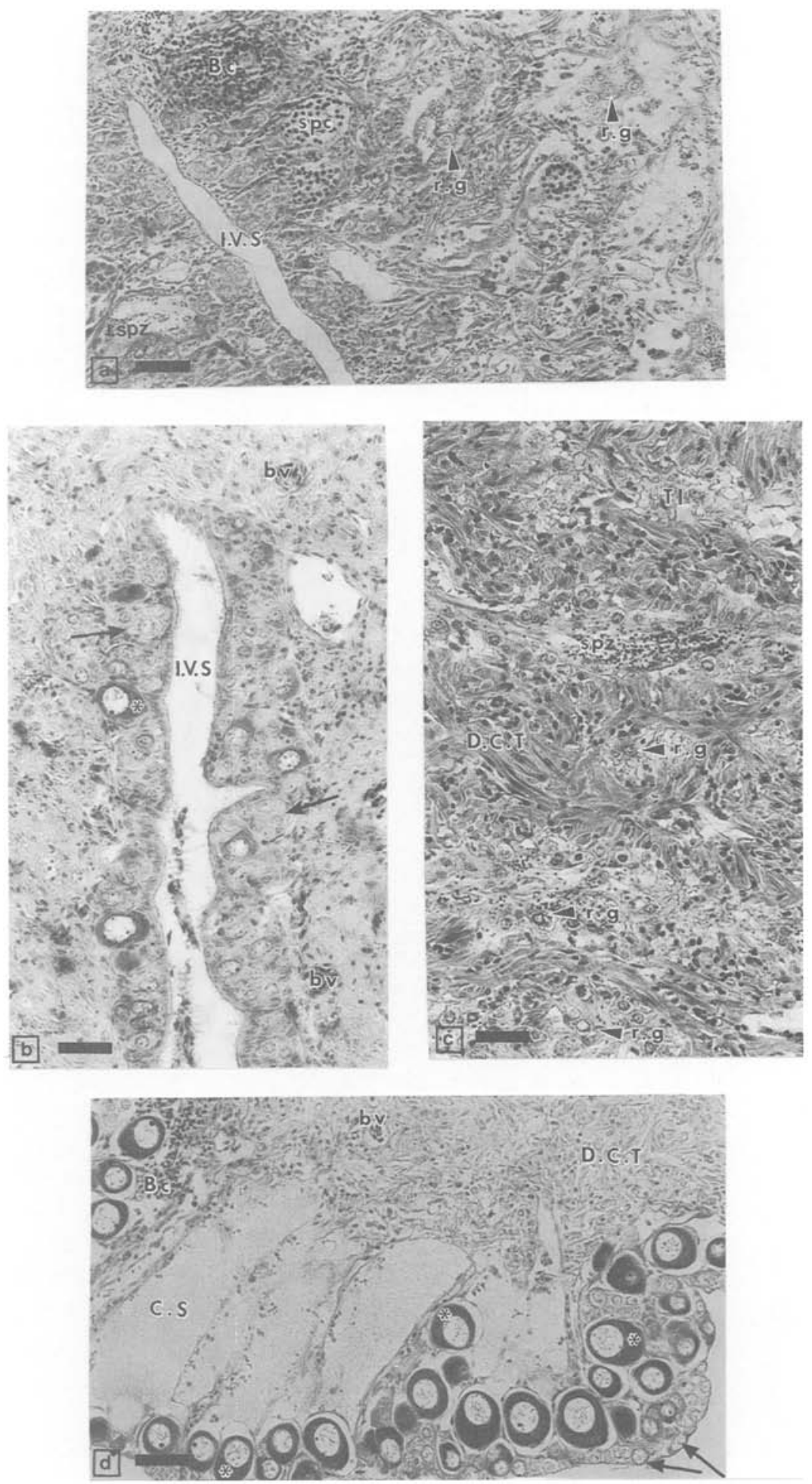

Fig. 6. Histological details of gonads during sex inversion in Lates calcarifer: a - Ventral side of transitional gonad at stage 1 (T1), scale $50 \mu \mathrm{m}, \mathrm{b}$ - ventral side of transitional gonad at stage 2 (T2), scale $40 \mu \mathrm{m}, \mathrm{c}$-dorsal side of the same gonad (T2), scale $40 \mu \mathrm{m}, \mathrm{d}$ - ventral side of transitional gonad at stage 3 (T3), scale $50 \mu \mathrm{m}$. Bc = basophilic cells, bv: blood vessel, C.S - connective stroma, D.C.T = dense connective tissue, I.V.S = invagination of the ventral side of the gonad, spc = spermatocytes, r.g = residual gonia, r.spz = residual spermatozoon, $\mathrm{Tl}=$ testicular lobules, asterisks indicate previtellogenic oocytes, arrows indicate gonia. 
inversion were seen in male post-spawning gonads (M4) in which all male germinal cells were degenerating. Some gonia, spermatogenic cysts and residual spermatozoa sometimes remained in testicular lobules, that seemed to collapse. However, gonia and spermatogenic cysts usually occupied atypical locations in the lumen of testicular lobules. At this stage no ovarian tissue could be seen (Fig. 6a). Clusters of basophilic cells, which sometimes contained dark pigment, were frequently noticed in these gonads as well as an augmentation of their vascularization, especially toward the periphery. These two features were characteristic of all transitional gonads.

Transitional stage 2 (T2) = This stage was characterized by the first appearance of clusters of gonia, meiotic oocytes, and very young previtellogenic oocytes along the ventral side of the gonad. These clusters of female germinal cclls arc particularly located at the bottom of invaginations which occurred from the ventral side of these gonads (Fig. 6b). Concomitantly, the degenerating testicular tissue was found at this time mostly close to the dorsal side (Fig. 6c), with the ventral part of the gonad largely occupied by connective tissue (see T2 in Figure 5).

Transitional stage 3 (T3) $=$ At this stage, the ovarian tissue was represented by a nearly continuous layer of previtellogenic oocytes, gonia, and meiotic oocytes located along the whole ventral side of the gonad. The rest of the gonad consisted mainly of dense connective-tissue (more than $50 \%$ of one histological cross-section of the gonad), in which no testicular tissue could be found (see T3 in Figure 5). An intermediate zone formed by loose connective tissue could be seen between the layer of ovarian tissue and the dense connective tissue (Fig. 6d). The invaginations of the ventral side of the gonad developed and ramified into the connective tissue to give rise to digitations that outlined the future ovarian lamellae (see T3 in Figure 5). In these gonads, a development of the connective tissue containing some germinal cells became apparent along the inner side of each of the latero-dorsal lobes (Fig. 7b).

Transitional stage 4 (T4) = Oocytes have invaded the connective tissue in a centripetal way, with the latter representing less than $50 \%$ of one histological cross-section of the gonad (Fig. 7a). The future ovarian lamellae were now clearly observable. This stage appeared to occur just prior to the formation of the ovary, and began with the outfolding of the latero-dorsal lobes which finally met and closed ventrally to form a hollow structure (as indicated by the curved arrows in transitional gonads stages T4 and closed T4 in Figure 5). Concomitantly, the development of connective tissue in each latero-dorsal lobe expanded to give rise to a thin membrane that would become involved in the formation of the ventral wall of the future ovary (Fig. 7c). This, however, was often broken during dissection and fixation. Although the formation of a closed ovary occurred most frequently at this stage, gonads that already were closed could sometimes be observed at the earlier transitional stage 3 (T3).

Numerous histological observations of sections through whole-fixed transitional gonads at each stage of sex inversion have shown that these were homogenous whatever the observed section (anterior, median or posterior part).

Morphologically, all transitional gonads were typically smaller than testes and were red-pink in colour, probably because of extensive peripheral blood irrigation, which was also noticeable in histological cross-sections (Fig. 6b, 7b).

\section{Sex inversion period}

The period of sex inversion, characterized by the presence of transitional animals (Fig. 4, 8), extended from January to April, that is, between the reproductive season (October-February) and the resting period (March-September). However, fish that were undergoing sex inversion were more numerous at the beginning of the resting period $(15 \%$ in March and $30 \%$ in April) than at the end of the reproductive period, and the percentage of males declined significantly only in April $(\mathrm{p}<0.05)$. Furthermore, the sex inversion process was not synchronous in the male population inasmuch as transitional stages (T2 and T3) were found in January and April, and the first stagc T4 was detected as carly as February. During this period, daylength decreased, although temperatures increased until April, when sexual inversion was at its height. 

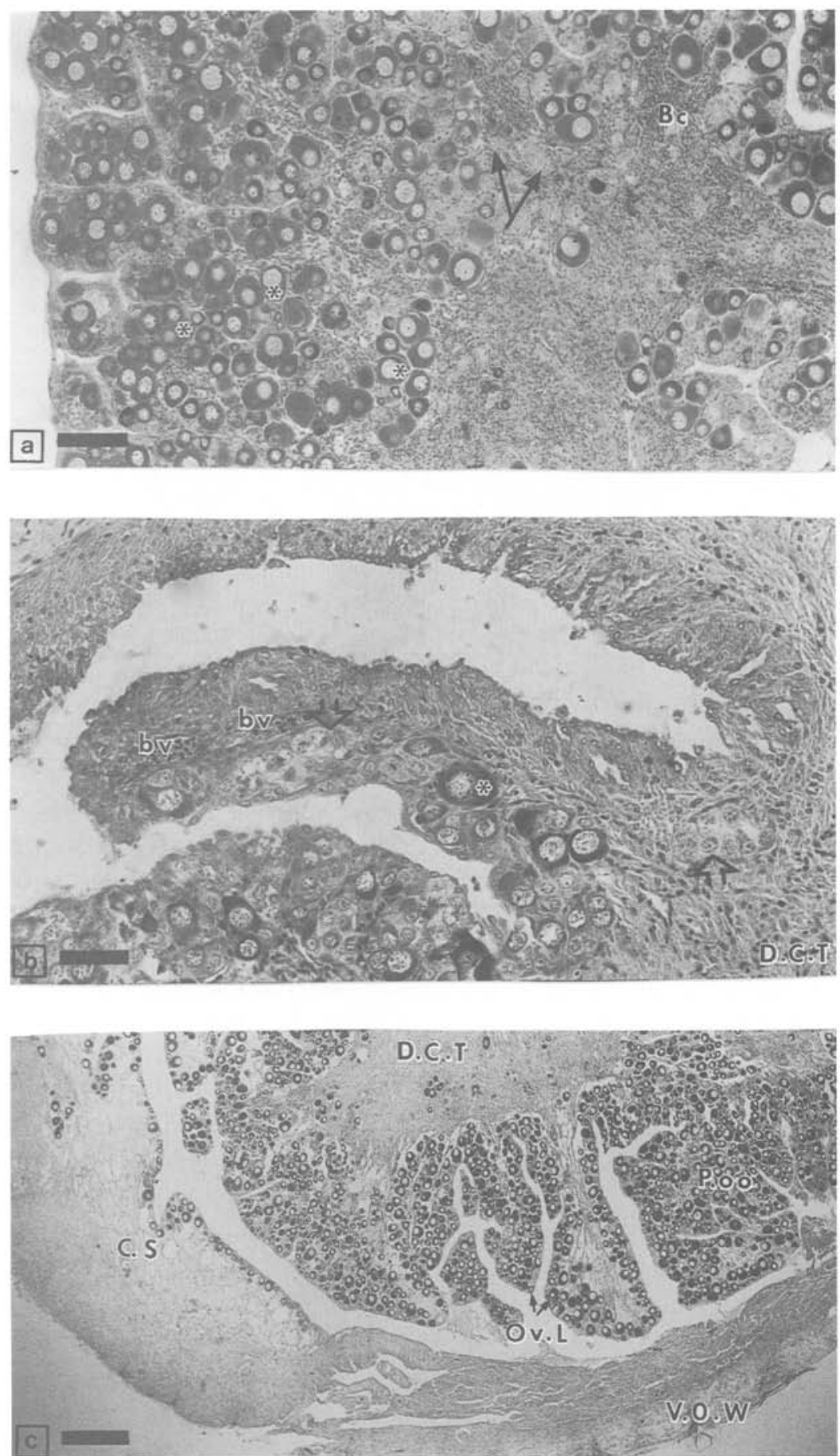

Fig. 7. Histological details of gonads during sex inversion in Lates calcarifer: a - Transitional gonad at stage 4 (T4), scale $250 \mu \mathrm{m}, \mathrm{b}-$ expansion of connective tissue with female germinal cells on the dorsal side of a transitional gonad at stage 3 (T3), scale $50 \mu \mathrm{m}, \mathrm{c}-$ ventral side of a transitional gonad at stage $4(\mathrm{~T} 4)$, scale $320 \mu \mathrm{m} . \mathrm{Bc}=$ basophilic cells, bv $=$ blood vessel, C. $S=$ connective stroma, D.C. $\mathrm{T}=$ dense connective tissue, V.O.W = ventral ovarian wall, P.oo and asterisks indicate previtellogenic oocytes, arrows indicate gonia, double-arrows indicate meiotic oocytes. 


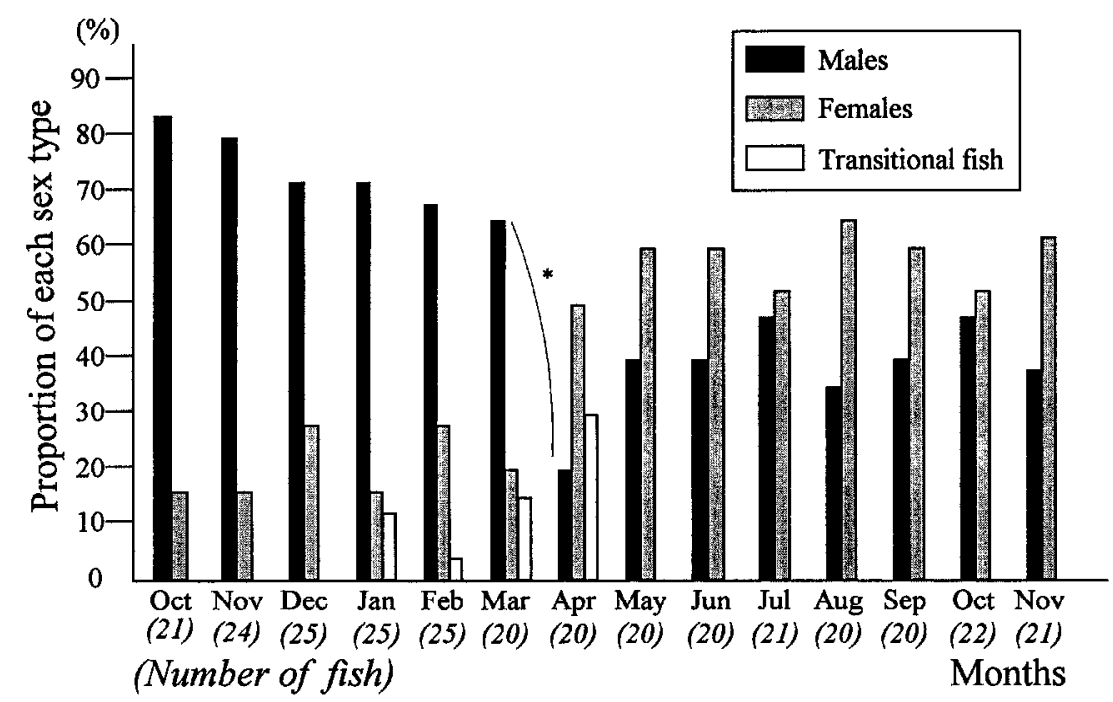

Fig. 8. Changes in proportion of sexual types during the reproductive cycle of the seabass, Lates calcarifer.

\section{Rate of sex inversion within the population}

The proportion of males changed from $73 \%$ before the period of sex inversion (mean from October to March), to $40 \%$ after this period (mean from May to November) (Fig. 8). The annual proportion of fish undergoing sex inversion was about $45 \%$ for this cohort which was three-year-old at the beginning of the experiment.

\section{Size at inversion}

Significant differences in the average eviscerated weight, body weight, and standard length were found between males and females (higher female weight and size, $p<0.01$ ), and only for the eviscerated weight between males and transitional fish (higher transitional fish weight, $\mathrm{p}<0.05$ ). However, no difference could be found between transitional fish and females (see Table 2). Furthermore, the size-frequency distribution (represented by the eviscerated weight in Figure 9) showed a significant overlap among all sex types.

\section{Discussion}

As a consequence of its wide geographic distribution (Grey 1987), a large range of variation can be seen in the reproductive timing of the seabass, Lates calcarifer. In Tahiti $\left(17^{\circ} 30^{\prime} \mathrm{S}\right)$, this species exhibited a single annual reproductive period at the beginning of the warm, wet season. In the tropical southern hemisphere, the same timing as Tahiti was recorded in Australia (Davis 1985) and in Papua New Guinea (Moore 1982) (respectively $12-17^{\circ} \mathrm{S}$ and $7^{\circ} \mathrm{S}$ ). Reproduction in equatorial countries such as Singapore $\left(1^{\circ} \mathrm{N}\right)$ (Lim et al. 1986) seemed to be continuous, with a peak of sexual activity from AprilMay to September-October. In the tropical northern hemisphere, there also was a single annual reproductive period during the summer monsoon season, for example, in Chilkla Lake in India $\left(19^{\circ} \mathrm{N}\right)$ (Patnaik \& Jena 1976) and Beng West $\left(22^{\circ} \mathrm{N}\right)(\mathrm{De} 1971)$.

Although photoperiod and temperature have been the most frequently studied environmental factors that are able to control sexual cycling in fish (de Vlaming 1972), few such data are available on the synchronization of gonadal development in Lates calcarifer. In Tahiti, gonadal development was concomitant with rising temperature and increasing daylength, as in another tropical Australian fish Therapon unicolor (Beumer 1979) and severàl temperate species (Billard \& Breton 1981). There are, however, no accurate data on the synchronization of gonadal development with changes in photoperiod or temperature, although some influence of temperature on gonadal development in the seabass has been suggested (Grey 1987). In 


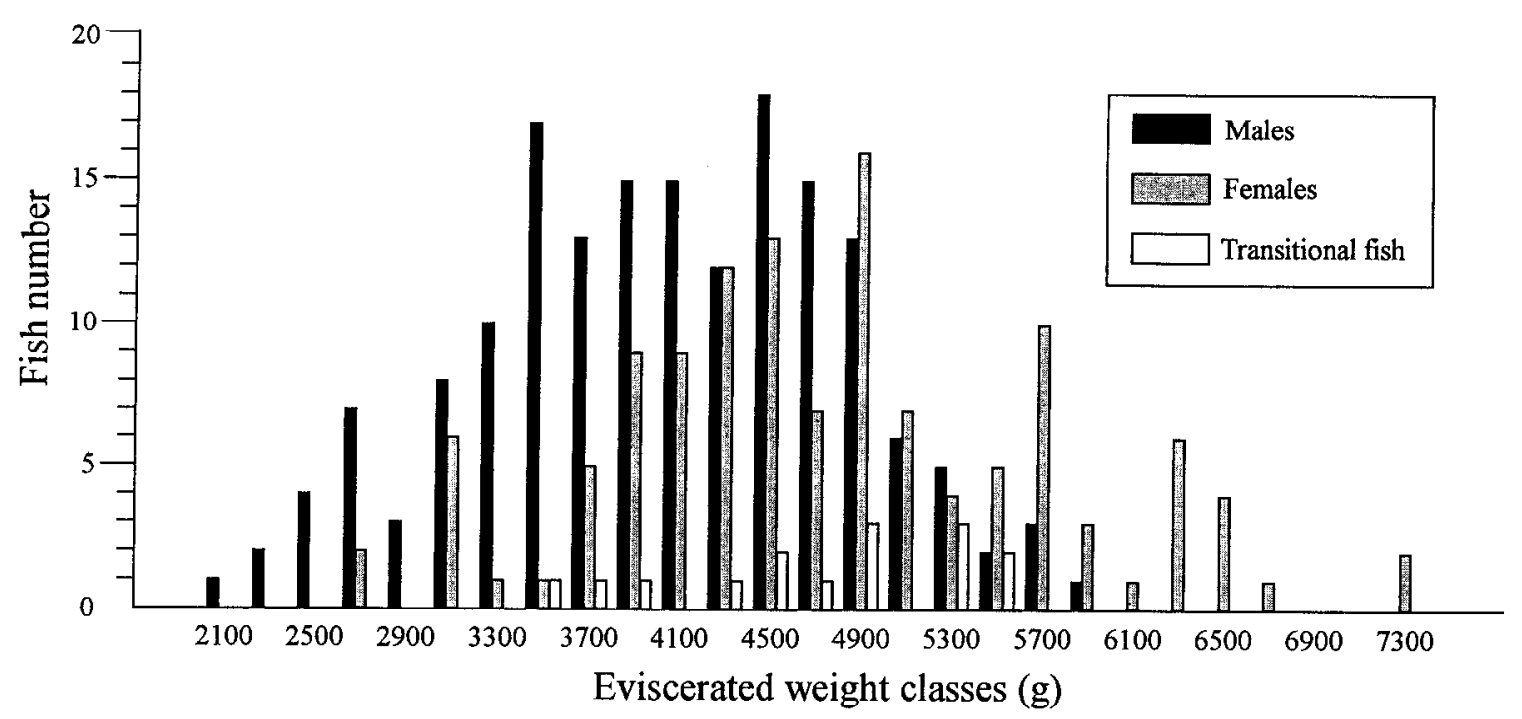

Fig. 9. Frequency distribution of specimen size (eviscerated weight in $\mathrm{g}$ ) for each sex type in the sampled population of captive seabass, Lates calcarcifer (class interval $-200 \mathrm{~g}$ ).

French Polynesia, the resting period of Lates calcarifer began while the temperature was still increasing, suggesting that photoperiod could be one of the main factors for its sexual cycling. Rainfall increased at nearly the same time as temperature and daylength, but rainfall did not seem to be a regulatory factor inasmuch as seabass underwent normal gonadal development (Thouard personal communication) in artificial conditions of increasing photoperiod and temperature. On the other hand, in the area of the natural distribution of the species, the beginning of the spawning period appeared to be synchronized by the onset of the local monsoon (Moore 1982, Davis 1985), suggesting that rainfall, or the consequences of rainfall, were required as spawning stimuli. According to Davis (1985), synchronization at that time allowed juveniles to take advantages of the aquatic habitats created by rainfall.
Under our experimental conditions, no ovulated female, or female undergoing oocyte maturation, was detected. However, oocyte maturation and ovulation can be triggered by LHRHa in Lates calcarifer at the vitellogenesis time (Harvey et al. 1985, Lim et al. 1986, Garcia 1989a, 1990, 1992), and treated females spawn several times every 24 hours. This short duration of final maturation and ovulation stages has been suggested as an explanation for the low proportion of female groupers, Epinephelus tauvina, found to be undergoing oocyte maturation (Abu-hakima 1987). Another explanation, however, could be the lack of adequate natural stimuli triggering oocyte maturation, ovulation, and spawning. Under natural conditions, seabass migrate downstream before spawning (Grey 1987), and this takes place near the mouth of rivers during the wet season. At this time, environmental factors such as the rising tide, water temperature, salinity

Table 2. Standard length, body weight and eviscerated weight in males, transitional fish and females of the seabass, Lates calcarifer.

\begin{tabular}{llll}
\hline Sex type & Eviscerated weight $(\mathrm{g})$ & Body weight $(\mathrm{g})$ & Standard length $(\mathrm{mm})$ \\
\hline Male $(\mathrm{N}=170)$ & $4042 \pm 61\left(\mathrm{~F}^{* *}\right)$ & $4310 \pm 66\left(\mathrm{~F}^{* *}\right)$ & $556 \pm 4\left(\mathrm{~F}^{* *}\right)$ \\
Transitional $(\mathrm{N}=15)$ & $4716 \pm 171\left(\mathrm{M}^{*}\right)$ & $5015 \pm 189$ & $578 \pm 7$ \\
Female $(\mathrm{N}=123)$ & $4778 \pm 86$ & $5213 \pm 95$ & $587 \pm 3$
\end{tabular}

Mean \pm standard error for the whole experiment.

$\because$ or $* *$ significant difference $\mathrm{p}<0.05$ or $\mathrm{p}<0.01$ between sex type and male $(\mathrm{M})$ or female $(\mathrm{F})$. 
(Kungvankij 1987), or the presence of dissolved organic material (Moore 1982) could act as natural stimuli. Furthermore, the peak of multiple spawnings coincided with declining tides of quarter-moon periods, suggesting a semilunar spawning rhythm (Garcia 1992).

It should be pointed out that in Tahiti, some ovulated females have been found among fish maintained under the same rearing conditions as ours. These females were detected only during January and February. This finding appears to rule out the hypothesis that unfavourable rearing conditions affected the triggering of oocyte maturation and ovulation in our females. The detection of ovulation in January-February, as well as the finding of all females at the atretic stage (F4) in March, suggests ovulation and perhaps spawning during the months of January-February in French Polyncsia.

Moore (1979) was the first to describe the process of sex inversion of the seabass, Lates calcarifer, in Papua New Guinea. According to body-length-frequency distributions, the detection of transitional gonads, and biopsy experiments, he concluded that the seabass was a protandrous hermaphrodite and that sex inversion required a complete reorganization of its gonadal structure. These results were confirmed later by Davis (1982) in Australia. Both of these authors stated that transitional gonads could not be detected by their general morphology. However, they regarded as transitional, all gonads that showed morphological and histological features of testes as well as some young previtellogenic oocytes along the ventral lobes. We found similar oocytes in a large number of histological cross-sections of testes at all testicular maturation stages. These oocytes, called testis-ova (Atz 1964) or oocyte-likecells, seem to be present in male gonads at all stages in all known protandric teleosts (Reinboth 1988). Moreover, they can be found in gonochoristic species in which they look perfectly identical to female previtellogenic oocytes, even at the ultrastructural level (Bruslé \& Bruslé 1983). In fact, Sadovy \& Shapiro (1987) have concluded that the presence of this type of oocyte within spermatogenic tissue does not characterize a transitional sex inversion stage. In the present study, first transitional stages (T1), were recognized by the presence of degenerating testic- ular tissue. Immediately after this, the first female germinal cells were found in the ventral part of the gonad, always accompanied by some degenerating testicular tissue on the dorsal side (T2). Finally, a centripetal proliferation of ovarian tissue occurred (T3 and T4). According to these criteria, all transitional gonads were found to be smaller than testes and to have a typical red-pink color. This seemed to be the result of an extensive peripheral vascularization. The same observation has been reported previously in this species, but only in newly-inversed female gonads (Moore 1979). It would be interesting to know whether the presence of blood cells play a determining role in the process of sex inversion. Peripheral vascularization near proliferating ovarian tissue may suggest some hormonal action (extra-gonadal steroids, pituitary hormones) as has becn shown for the action of gonadotropin on sex inversion in Monopterus albus (Tang et al.1974) and in Thalassoma bifasciatum (Koulish \& Kramer 1989). Involvement of other hypophysial hormones, such as ACTH, GH or prolactin on the sex inversion process has been suggested by Reinboth (1988), and Ross (1987) has suggested that sex inversion and growth could be under the same endocrine control in Thalassoma duperrey.

Another possibility is that the immune system takes an active part in the elimination of degenerating testicular lissue. A similar increase in blood cells or blood vessels has been noticed in the degenerating ovarian lamellae of some protogynous fish: $X y r-$ ichtys pentadactylus (Nemtzov 1985), Scolopsi taeniopterus, Scolopsis monogramma (Young \& Martin 1985), Hemanthias vivanus (Hasting 1981), and Mycteroperca microlepis (Roberts \& Schlieder 1983). Moreover, immune cell proliferation has been noticed in the degenerating testicular part of the ovotestis of the protandrous sparid, Lithognatus mormyrus (Besseau \& Faliex 1990, Besseau 1991).

From a histological point of view, sex inversion in Lates calcarifer appears to be a very particular process, especially because of the extensive morphological changes involved (Moore 1979, Davis 1982). Based on a large number of histological observations, we have given a chronological description of this process which is characterized by testicular tissue degeneration, centripetal proliferation of ovari- 
an tissue, and formation of the future ovary. In the seabass, Lates calcarifer, we showed that there was no longitudinal heterogeneity in the distribution of these different stages of sex inversion throughout transitional gonads, but only a centripetal zonation of germinal cells. A longitudinal heterogeneity in the distribution of male and female gonadal tissues during sex inversion has been described in the gonads of some hermaphroditic fish, such as Hemanthias peruanus (Coleman 1983), Eleginops maclovinus (Calvo et al.1992), and Coris julis (Bruslé 1987). In Lates calcarifer, the absence of any longitudinal heterogeneity in gonads during sex inversion makes possible a correct assessment of the transitional stage from the observation of only a single crosssection of the gonad.

According to the configuration of testicular and ovarian tissues, the gonads of this species can be classified as an undelimited type, that is without a connective membrane between the male and female tissues, but with distinct male and female gonadal tissue (Sadovy \& Shapiro 1987). Furthermore, ovarian tissue was lacking throughout the entire functional male period, with the exception of oocyte-like-cells which did not form ovarian tissue, but remained isolated female germinal cells within the testicular tissue. Among protandrous fish, this type of gonad has been described in only one species, Inegocia japonica (Platycephalidae), in which a similar reorganization of gonadal morphology has been shown (Fujii 1971). However, the outfolding of the transitional gonad occurred dorsally in Inegocia japonica, and not ventrally as in Lates calcarifer.

With regard to the sex inversion period, some hermaphroditic fish undergo natural sex inversion at the end of the reproductive season. These are protogynous forms: Monopterus albus (Chan \& Phillips 1967), Anthias squamipinnis (Fishelson 1975), Pseudolabrus celidotus (Jones 1980), Epinephelus guaza and E. aeneus (Bruslé \& Bruslé 1975), E. tauvina (Abu-hakima 1987), and protandrous ones: Gonostoma gracile (Kawaguchi \& Marumo 1967), Acanthopagrus australis (Pollock 1985), and Sparus aurata (7ohar et al. 1978). In the present study, it was found that in Lates calcarifer introduced into French Polynesia, sex inversion was also a post-spawning event, as described previously in
Australia by Davis (1982) and in Papua New Guinea by Moore (1979). In our case, however, a small proportion of transitional fish was also found at the end of the reproductive period (January and February). This could be the reflection of individual heterogeneity in the beginning of the male post-spawning period, inasmuch as sex inversion took place in post-spawning male gonads. Heterogeneity in the beginning of the male post-spawning period, and the fact that complete sex inversion, from a fluant male to a newly-inverted female, could take place in less than 17 days (unpublished data), may well have prevented the detection of synchronous sex inversion in all transitional fish.

During our experiment, the percentage of sex inversion within the male population was about $45 \%$. This highly skewed sex ratio could be the result of particular conditions of captivity. Firstly, fish used for the experiment were of the same age. Whether sex inversion is triggered by attainment of a certain age and/or size still remains unclear, although the bimodal size frequency distribution found in many hermaphroditic species raises this possibility (Sadovy \& Shapiro 1987). Our results concerning the size differences between males and transitional fish, and between males and females also suggest the hypothesis that sex inversion could occur when a critical threshold size is attained by a given homogenous age-group of fish. Similar observations have been made in captive groups of seabass of the same age in which males were always smaller than females (Lim et al. 1986). In the grouper, Epinephelus diacanthus, males are always bigger than females whatever the age group (Chen et al. 1980). In Thalassoma duperrey, the largest females have a greater tendency to undergo sex inversion to become secondary males in a given age group of fish (Kimura et al. 1992). Conversely, in Gonostoma bathyphilum, the smallest males changed sex preferentially (Badcock 1986). In Lates calcarifer, however, the significant overlap in size among sex types, suggests that size is not the only factor able to trigger sex inversion.

It is now well known that sex inversion can be initiated through behavioral signals, especially in species with social groups limited in size (Shapiro 1985, 1988, Ross 1990). Captivity could result in an inten- 
sification of behavioral signals by artificially creating such social groups. It has been shown in another protandrous hermaphrodite fish, the seabream, Sparus aurata, that special conditions of captivity could influence sex inversion (Zohar et al. 1984). In this species, the presence of old females decreased the proportion of sex inversion of young males and, the presence of young males increased the sex proportion of old males that changed sex. In the same way, in captivity stock of the grouper, Epinephelus microdon, deviations in sex ratio could lead to individuals changing sex from female to male and even from male to female, producing an adjustment at approximatively a 1:1 ratio (Debas 1989, Debas et al. 1990). In Gonostoma bathyphilum, sex inversion occurred when threshold critical densities were attained in a given population (Badcock 1986). In a similar way, we could imaginc that the low proportion of females $(26.5 \%)$ or the high proportion of males $(73.5 \%)$ before the sex-inversion period could influence the rate of sex inversion in the seabass, Lates calcarifer. These two hypotheses of a critical size and a social control for sex inversion seem likely to be involved together in the explanation of this high percentage.

\section{Acknowledgements}

This work was funded in part by a GCS/BBA tropical fund. The authors are indebted to the Aquacop aquaculture team (COP, I.F.R.E.M.E.R.), and especially the fish staff, for their assistance in providing fish and experimental facilities.

\section{References cited}

Abu-hakima, R. 1987. Aspects of the reproductive biology of the grouper Epinephelus tauvina (Forskål), in Kuwaiti waters. J. Fish Biol. 30: 213-222.

Aquacop, J. Fuchs, G. Nedelec \& E. Gasset. 1990. Selection of finfish species as candidates for aquaculture in French Polynesia. pp. 461-484. In: Ifremer (ed.) Advances in Tropical Aquaculture, Proceeding of a Workshop, 20 February - 4 March, Tahiti.

Atz, J.W. 1964. Intersexuality in fishes. pp. 142-232. In: C.N.
Armstrong \& A.J. Marshall (ed.) Intersexuality in Vertebrate Including Man, Academic Press, New York.

Badcock, J. 1986. Aspects of the reproductive biology of Gonostoma bathyphilum (Gonostomidae). J. Fish Biol. 29: 589-603.

Besseau, L. 1991. L'hermaphrodisme protandre chez les sparidés: les potentialités de l'ovotestis dans le modèle Lithograuhus mormyrus. Thèse de doctorat de l'université de Perpignan. $231 \mathrm{pp}$.

Besseau, L. \& E. Faliex. 1990. Présence de granulocytes et de 'corps bruns' dans l'ovotestis de marbré, Lithognathus mormyrus (L.) (Téléostéen, Sparidé). Ichtyophysiologica Acta 13: 109-114.

Beumer, J.P. 1979. Reproductive cycles of two Australian freshwater fishes: the spangled perch, Therapon unicolor Gunther, 1859 and the East Queensland rainbowfish, Nematocentris splendida Peters, 1866. J. Fish Biol 15: 111-134.

Billard, R. \& B. Breton. 1981. Le cycle reproducteur chez les poissons téléostéens. Cahier du laboratoire de Montereau 12: 4356.

Bruslé, J. \& S. Bruslé. 1975. Ovarian and testicular intersexuality in two protogynous Mediteranean groupers, Epinephelus aeneus and Epinephelus guaza. pp. 222-227. In: R. Reinboth (ed.) Intersexuality in the Animal Kingdom, Springer-Verlag, Berlin.

Bruslé, J. \& S. Bruslé. 1983. La gonadogenèse des poissons. Reprod. Nutr. Develop. 23: 453-491.

Bruslê, S. 1987. Sex-inversion of the hermaphroditic, protogynous teleost Coris julis L. (Labridae). J. Fish Biol. 30: 605-616.

Calvo, J., E. Morriconi, G.A. Rae \& N.A. Sanroman. 1992. Evidence of protandry in a subantarctic notothenid, Eleginops maclovinus (Cuv. \& Val., 1830) from the Beagle channel, Argentina. J. Fish Biol. 40: 157-164.

Chan, S.T.H. \& J.G. Phillips. 1967. The structure of the gonads during natural sex reversal in Monopterus albus. J. Zool. Lond. 151: 129-141.

Chen, C.P., H.L. Hsieh \& K.H. Chang. 1980. Some aspects of the sex change and reproductive biology of the grouper, Epinephelus diacanthus (Cuvier \& Valanciensis). Bull. Inst. Zool., Academia Sinica 19: 11-17.

Coleman, F. 1983. Hemanthias peruanus, another hermaphroditic anthiine serranid. Copeia 1983: 252-253.

Davis, T.L.O. 1982. Maturity and sexuality in barramundi Lates calcarifer (Bloch), in the northern territory and south-eastern Gulf of Carpentaria. Aust. J. Mar. Freshw. Res. 33: 529-545.

Davis, T.L.O. 1984. A population of sexually precocious barramundi Lates calcarifer, in the Gulf of Carpetaria, Australia. Copeia 1984: 144-149.

Davis, T.L.O. 1985. Seasonal changes in gonad maturity, and abundance of larvae and early juveniles of barramundi, Lates calcarifer (Bloch), in Van Diemen Gulf and the Gulf of Carpentaria. Aust. J. Freshw. Res. 36: 177-190.

Davis, T.L.O. 1987. Biology of wildstock Lates calcarifer in northern Australia. pp. 22-29. Int: J.W. Copland \& D.L. Grey (eds.) Management of Wild and Cultured Seabass/Barramundi (Lates calcarifer), Proceedings of an International Workshop, 24-30 September 1986, Darwin. 
De, G.K. 1971. On the biology of postlarval and juvenile stages of Lates calcarifer (Bloch). Journal of the Indian Fisheries Association 1: 5464.

Debas, L. 1989. Etude biométrique, histologique et endocrinologique de la sexualité du mérou Epinephelus microdon dans le milieu naturel et en élevage: caractérisation de l'hermaphrodisme protérogyne, description du phénomène d'inversion et mise en évidence du phénomène de réversion. Thèse de doctorat de l'université d'Aix-Marseille II. 108 pp.

Debas, L., A. Fostier, J. Fuchs, M. Weppe, G. Nedelec, A. Benett, Aquacop, C. Cauty \& B. Jalabert. 1990. The sexuality of cultured hermaphroditic fish species: analysis of morphological and endocrinological features in a protogynous hermaphrodite, Epinephelus microdon, as a basis for further research to control reproduction in the grouper. pp. 543-557. In: Ifremer (ed.) Advances in Tropical Aquaculture, Proceedings of a Workshop, 20 February - 4 March, Tahiti.

de Vlaming, V.L. 1972. Environmental control of teleost reproductive cycles: a brief review. J. Fish Biol. 4: 131-140.

Fishelson, L. 1975. Ecology and physiology of sex reversal in Anthias squamipinnis (Peters) (Teleostei: Anthiidae). pp. 284294. In: R. Reinboth (ed.) Intersexuality in the Animal Kingdom, Springer-Verlag, Berlin.

Fuchs, J. 1987. Growth of introduced larvae and fingerlings of seabass (Lates calcarifer) in Tahiti. pp. 189-192. In: J.W. Copland \& D.L. Grey (eds.) Management of Wild and Cultured Seabass/Barramundi (Lates calcarifer), Proceedings of an International Workshop, 24-30 September 1986, Darwin.

Fujii, T. 1971. Hermaphroditism and sex-reversal in fishes of the Platycephalidae-II. Kumococius detrusus and Inegocia japonica. Jap. J. Ichthyol. 18: 109-117.

Gabe. 1968. Techniques histologiques. Masson, Paris. 1113 pp.

Garcia, L.M.B. 1989a. Spawning reponse of mature female seabass, Lates calcarifer (Bloch), to a single injection of luteinizing hormone-releasing hormone analogue: effect of dose and initial oocyte size. J. Appl. Ichthyol. 5: 177-184.

Garcia, L.M.B. 1989b. Development of an ovarian biopsy technique in the seabass, Lates calcarifer. Aquaculture 77: 97-102.

Garcia, L.M.B. 1990. Advancement of sexual maturation and spawning of seabass, Laies calcarifer (Bloch), using pelleted luteinizing hormone-releasing hormone analogue and $17 \alpha$ methyltestosterone. Aquaculture 86: 33-345.

Garcia, L.M.B. 1992. Lunar synchronization of spawning in seabass, Lates calcarifer (Block): effect of luteinizing hormonereleasing hormone analogue (LHRHa) treatment. J. Fish Biol. 40: 359-370.

Grey, D.L. 1987. An overview of Lates calcarifer in Australia and Asia. pp. 15-29. In: J.W. Copland \& D.L. Grey (eds.) Management of Wild and Cultured Seabass/Barramundi (Lates calcarifer), Proceedings of an International Workshop, 24-30 September 1986, Darwin.

Harvey, B., J. Nacario, L.W. Crim, J.V. Juario \& C.L. Marte. 1985. Induced spawning of seabass, Lates calcarifer, and rabbitfish, Siganus guttatus, after implantation of pelleted LHRH analogue. Aquaculture 47: 53-59.

Hasting, P.A. 1981. Gonad morphology and sex succession in the protogynous hermaphrodite Hemanthias vivanus (Jordan \& Swain). J. Fish Biol. 18: 443-454.

Jones, G.P. 1980. Growth and reproduction in the protogynous hermaphrodite Pseudolabrus celidotus (Pisces: Labridae) in New Zealand. Copeia 1980: 660-675.

Kawaguchi, K. \& R. Marumo. 1967. Biolugy of Gonostoma gracile (Gonostomatidae) I. Morphology, life history and sex reversal. Infor. Bull. Planktology Jap. Commemoration Number of Dr. Y. Matsue: 53-69.

Kimura, S., Y. Nakayama \& K. Mori. 1992. Age and growth of the labrid fish Halichoeres poecilopterus in Ago Bay, Central Japan. Nippon Suisan Gakkaishi. 58: 811-817.

Koulish, S. \& C.R. Kramer. 1989. Human chorionic gonadotropin (hCG) induces gonad reversal in a protogynous fish, the bluehead wrasse, Thalassoma bifasciatum (Teleostei, Labridae). J. Exp. Zool. 252: 156-168.

Kungvankij, P. 1987. Induction of spawning of seabass (Lates calcarifer) by hormone injection and environmental manipulation. pp. 120-122. In: J.W. Copland \& D.L. Grey (eds.) Management of Wild and Cultured Seabass/Barramundi (Lates calcarifer), Proceedings of an International Workshop, 24-30 September 1986, Darwin.

Lim, L.C., H.H. Heng \& H.B. Lee. 1986. The induced breeding of seabass, Lates calcarifer (Bloch) in Singapore. Singapore $\mathbf{J}$. Pri. Ind. 14 (2): 81-95.

Moore, R. 1979. Natural sex inversion in the giant perch (Lates calcarifer). Aust. J. Mar. Freshw. Res. 30: 803-813.

Moore, R. 1982. Spawning and early life history of barramundi, Lates calcarifer (Bloch), in Papua New Guinea. Aust. J. Freshw. Res. 33: 647-661.

Nemtzov, S.C. 1985. Social control of sex change in the red sea razorfish Xyrichtys pentadactylus (Teleostei, Labridae). Env. Biol. Fish. 14: 199-211.

Patnaik, S. \& S. Jena. 1976. Some aspects of biology of Lates calcarifer (Bloch) from Chilka Lake. Indian J. Fish. 23: 65-71.

Pollock, B.R. 1985. The reproductive cycle of yellowfin bream, Acanthopagrus australis (Günther), with particular reference to protandrous sex inversion. J. Fish Biol. 26: 301-311.

Reinboth, R. 1988. Physiological problems of teleost ambisexuality. Env. Biol. Fish. 22: 249-259.

Roberts, D.E. \& R.A. Schlieder. 1983. Induced sex inversion, maturation, spawning and embryogeny of the protogynous grouper, Mycteroperca microlepis. J. World Maricul. Soc. 14: 639-649.

Ross, R.M.1987. Sex-change linked growth acceleration in a coral-reef fish, Thalassoma duperrey. J. Exp. Zool. 244: 455-461.

Ross, R.M. 1990. The evolution of sex-change mechanisms in fishes. Env. Biol. Fish. 29: 81-93.

Sadovy, Y. \& D.Y. Shapiro. 1987. Criteria for the diagnosis of hermaphroditism in fishes. Copeia 1987: 136-156.

Schwartz, D. 1963. Méthodes statistiques à l'usage des médecins et des biologistes. Flammarion, Paris. 306 pp.

Shapiro, D.Y. 1985. Behavioral influences on the initiation of adult sex change in coral reef fishes. pp. 583-585. In: B. Lofts \& W.N. Holmes (eds.) Current Trends in Comparative Endocrinology, Hong Kong University Press, Hong Kong. 
Shapiro, D.Y. 1988. Behavioral influences on gene structure and other new ideas concerning sex change in fishes. Env. Biol. Fish. 23: 283-297.

Tang, F., S.T.H. Chan \& B. Lofts. 1974. Effect of mammalian luteinizing hormone on the natural sex reversal of the rice-field eel, Monopterus albus (Zuiew). Gen. Comp. Endocrinol. 24: 242-248.

Young, P.C. \& R.B. Martin. 1985. Sex ratio and hermaphroditism in lethrinid fish from northern Australia. J. Fish Biol. 26: 273287.
Zohar, Y., M. Abraham \& H. Gordin. 1978. The gonadal cycle of the captivity-reared hermaphroditic teleost Sparus aurata (L.) during the first two years of life. Ann. Biol. Anim. Bioch. Biophys. 18: 877-882.

Zohar, Y., R. Billard \& C. Weil. 1984. La reproduction de la daurade (Sparus aurata) el du bar (Dicentrarchus labrax): connaissance du cycle sexuel et contrôle de la gamétogenèse et de la ponte. pp. 3-24. In: G. Barnabé \& R. Billard (eds.) L'Aquaculture du Bar es des Sparidés, I.N.R.A. Publ., Paris. 